\title{
Developing Interactive Multimedia In Animation Key To Improve The Spirit of Student Learning Vocational High School
}

\author{
Kadek Agus Hendra Pujawan 1, * \\ 1 Politeknik Ganesha Guru, Buleleng, Indonesia
}

\begin{abstract}
This study was aimed to (1) Design and Implement Interactive Multimedia Development in Animation Key in Multimedia class XII SMK Negeri 1 Sawan; (2) Find out students' responses and Achievment of Multimedia class XI toward Interactive Multimedia Development in animation Key. The types of research and development and using Dick and Carrey model, it involves Multimedia class XII SMK Negeri 1 Sawan in the academic year of 2014/2015. The source of data content expert and media expert are interview and questionnaire. Validity of interactive multimedia and student responses gained by using questionnaire, the data was analysed descriptive qualitatively and descriptive kuantitatively. The feedback of media expert then analysed thus, that media is valid and proper to be implemented in teaching learning process in the intened school. The results of student's responses data shows that the presentase of student who gave very positives responses was $64,2 \%$, presentase of student who gave positive responses was 35,8 \%, and none student to gave doubt responses, negative or even very negative response, the average scor was 43,69 . That scor shows that student' response toward material development was in very positive chategory.
\end{abstract}

Keywords:

Interactive Multimedia, Animation Key,

Dick and carey.

\section{Introduction}

In this globalization era, the ability to control information technology is indispensable. The role of information technology and communication (TIK) has been spreading through all aspects of life, including the field of education. The role of TIK in the education sector is to help giving theeducation information/message to the components of formal and non-formal education, intra-curricular and extra-curricular. In addition, to providing a message which are informative, descriptive, persuasive, and motivational, the role of TIK in education is expected to be more focus in pedagogical values, so many products TIK is created to be more containcurricular aspect (intra-curricular), with the hope of can give an effective and efficient contributionto reach the more optimal education goal.Products TIK in the intra-curricularis usually called as one of the learning media form (Laurahasiel, 2009). Learning media is one component in teaching and learning activities which is usually made by teachers at senior high school. Its function is as a distributor of the information from a source to receivers (Santyasa, 2007). SMKN 1 Sawan is a school that apply TIK in the process of learning, but in fact it is not fully implemented in school.There are many teachers who teach the students by using the conventional method. So that, it make students become saturated. There is still no interesting and variative learning media that can interact students's attention in the learning proccess. Another problem that was found related to the learning media is the contents of the learning media is not appropriate with competence and characteristic of students. These facts give spirit to researcher to solve these problemsin order to rich so minimum score criteria. Based on these problems, an interactive multimediawhich appropriate toteaching competence is needed especially in the key animation material.This is in line with Munadi (2008) staement, who states that interactive media with computer has some benefits, they are: (1) increase the students' motivation to study, in which the student needs are completed, the students will be

\footnotetext{
* Corresponding author.

E-mail Addresses: hendrapoltekg2stikom@gmail.com (Kadek Agus Hendra Pujawan)
} 
motivated to continue their study, (2) provide feedback, interactive learning media can provide an immediately feedback for the result study of the students. And (3) controll of the program is totaly in users, in this case the students itself. So that, a research on designing and implementing the interactive media is very needed.Based on the analysis of the productive subject group especially in the animation key subject, the students and teachers really need interactive multimedia which relevants to the animation key subject matter. By providing interactive multimedia which appropriate with the needs and characteristic of students, so it is expected to be held an effective and efficient proccess of learning. This media is combining and synchronize all mediawhich consist of text, graphic, photo, video, animation, music, narrative, and interactivitieswhich have been programmed based on the theory of learning.The benefit ofusing multimedia in teaching compared with another media are to increase the motivation to study, enable for the student to do the independent study, interactive, and also more efficient and effective "(Munadi, 2008). Application of multimedia is used to teach software, facilitate the student to learn how to get advantagesfrom multimedia, online learning and education marketing. The use of multimedia software in the learning process are to improve the efficiency, increased the motivation, facilitate active learning, facilitate experimental learning, consistent with student center learning, and leads to a better learning (Suyanto, 2005). By using the interactive multimedia, it is expected to solve these problems in learning process in the class XII Multimedia SMKN 1 Sawan.

\section{Method}

The kind of research that is used in this research is Development Research. Development Research is the effort to develop and produce a product such as material, media, tool and teaching strategy which can be used to solve the learning problem in the classroom/laboratory and it is not used to examine the theory (Soenarto, 2005). Development model that is used in this research is Dick and Carrey development model, this model is used to develop the teaching source of interactive multimedia key animation learning. The step of this model show the clear relationship, it is related each other. In other words, Dick and Carrey system is very brief and simple, but it contains the clear and systematic content (Dadang Supriatna, 2009). The subject of this research is the students of class XII Multimedia in SMK N 1 Sawan, and some experts as the media evaluator. Total students of class XII Multimedia is 30 students. The object of this research is the response of the experts, students and also the interactive multimedia which is developed. The data collections to be analyzed in this research are the validation of interactive multimedia cartoon key animation and also the response of the students. The tool for collecting the data is questioner. The questioner consists of some components such as the suitable content, language, and graphic. Likert Scale is used in the questioner to know the students' response. Data of students' response is analyzed by using descriptive statistic and it is concluded based on

class's average $(\bar{X}$ ) of students' response and interval in each category. Analysis of the validity of the content of an interactive multimedia intended to determine the extent of interactive multimedia that have been made to reach the criteria of teaching materials, the view of an interactive multimedia based on ratings validator designated by using sheets of expert validation, the results of expert validation is the basis and consideration in the revision in analysis descriptive qualitative. Table Conversion Response Students according to (Oemar Hamalik, 2001), they are, the criteria of $10 \leq<18$ included into the category of very negative, $18 \leq<26$ including negative categories, $26 \leq<34$ included into the category of undecided, $34 \leq<4234$ included in the positive category, and $42 \leq<50$ included in very positive.

\section{Result And Disscussion}

\section{Result}

Result of this research is an interactive multimedia product animation key which is practical and effective by using Adobe Flash CS 3 software as the main application, Cool Edit Pro as a sound editing software and Adobe Photoshop as an image editing software. Selection and the determination of the material is done by reviewing curriculum of productive subject groups of multimedia, syllabus, lesson plan and also student handbook in order to obtain a suitable package of an interactive multimedia. Here are the result of interactive multimedia animation key development. 


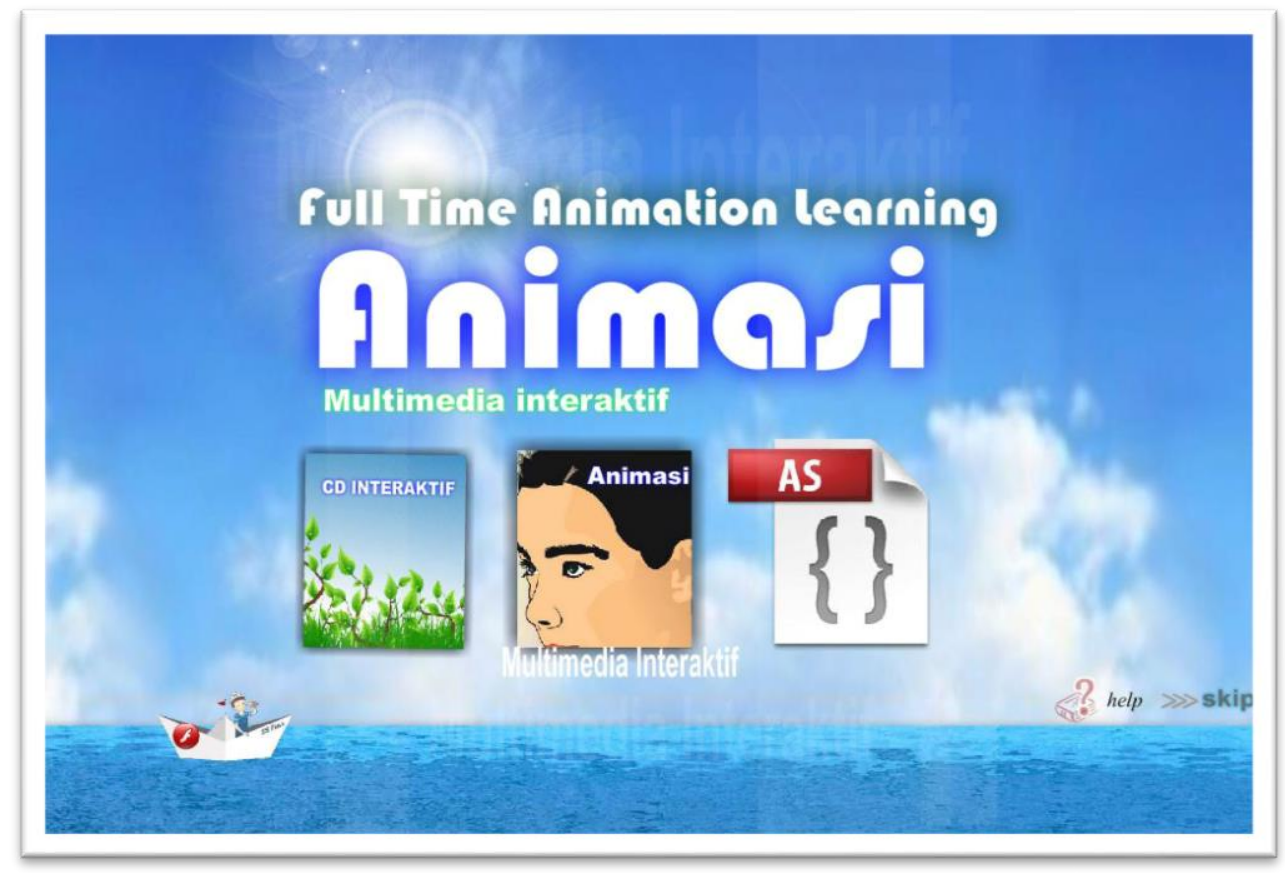

Figure 1. Intro Page View

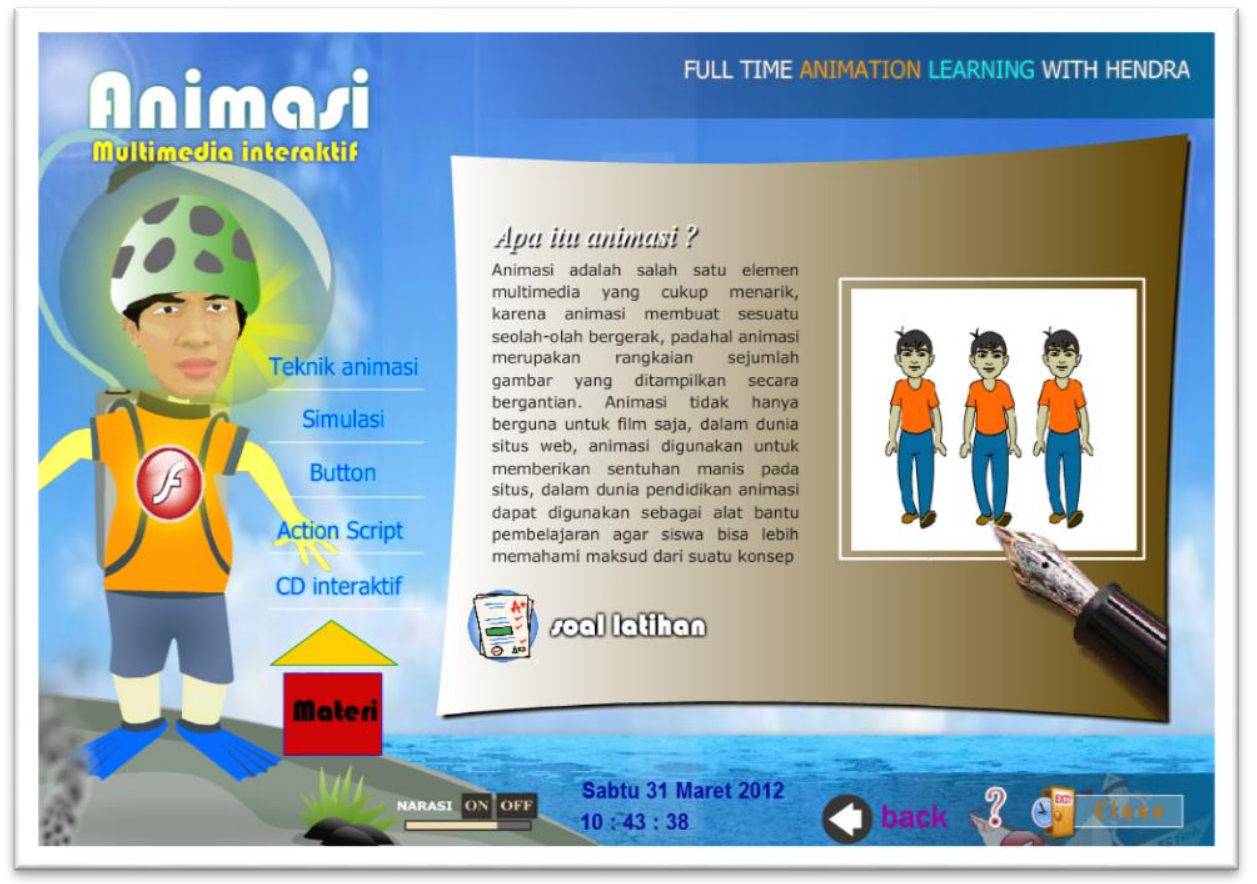

Figure 2. The View of Main Menu Page 


\section{Inimaง}

multimedia interaktif

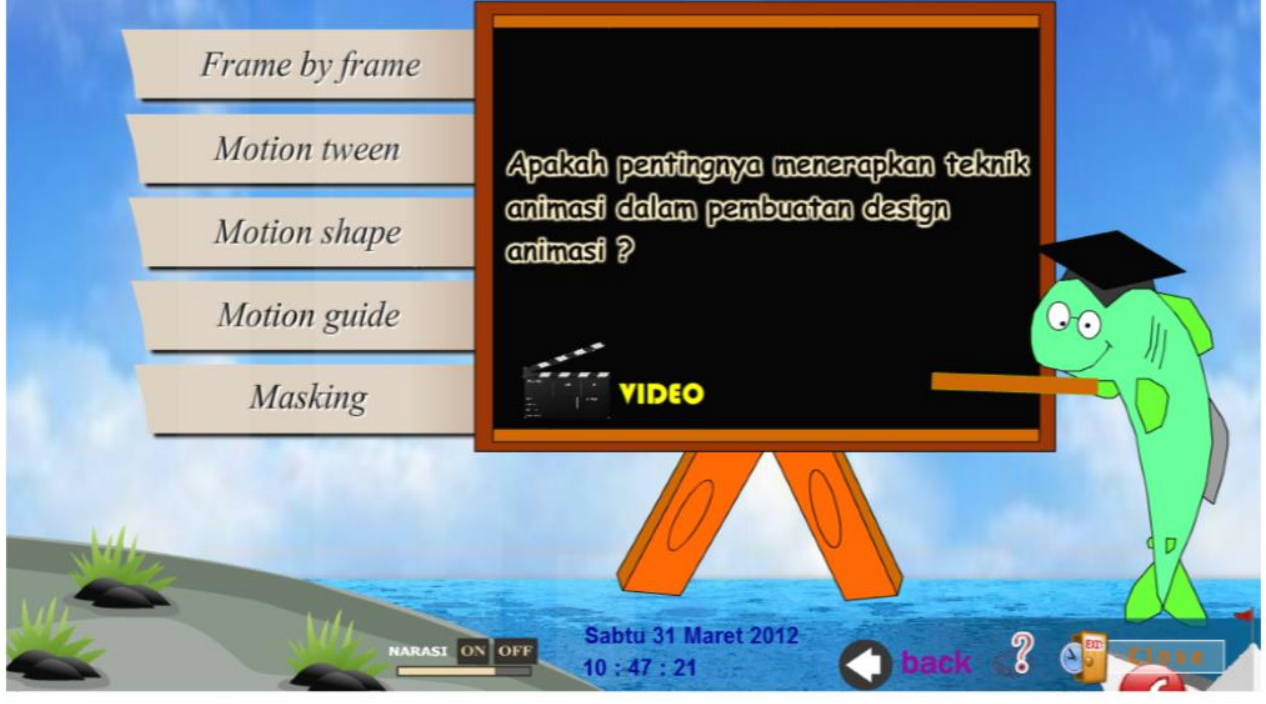

Figure 3. The View of Sub Menu Page

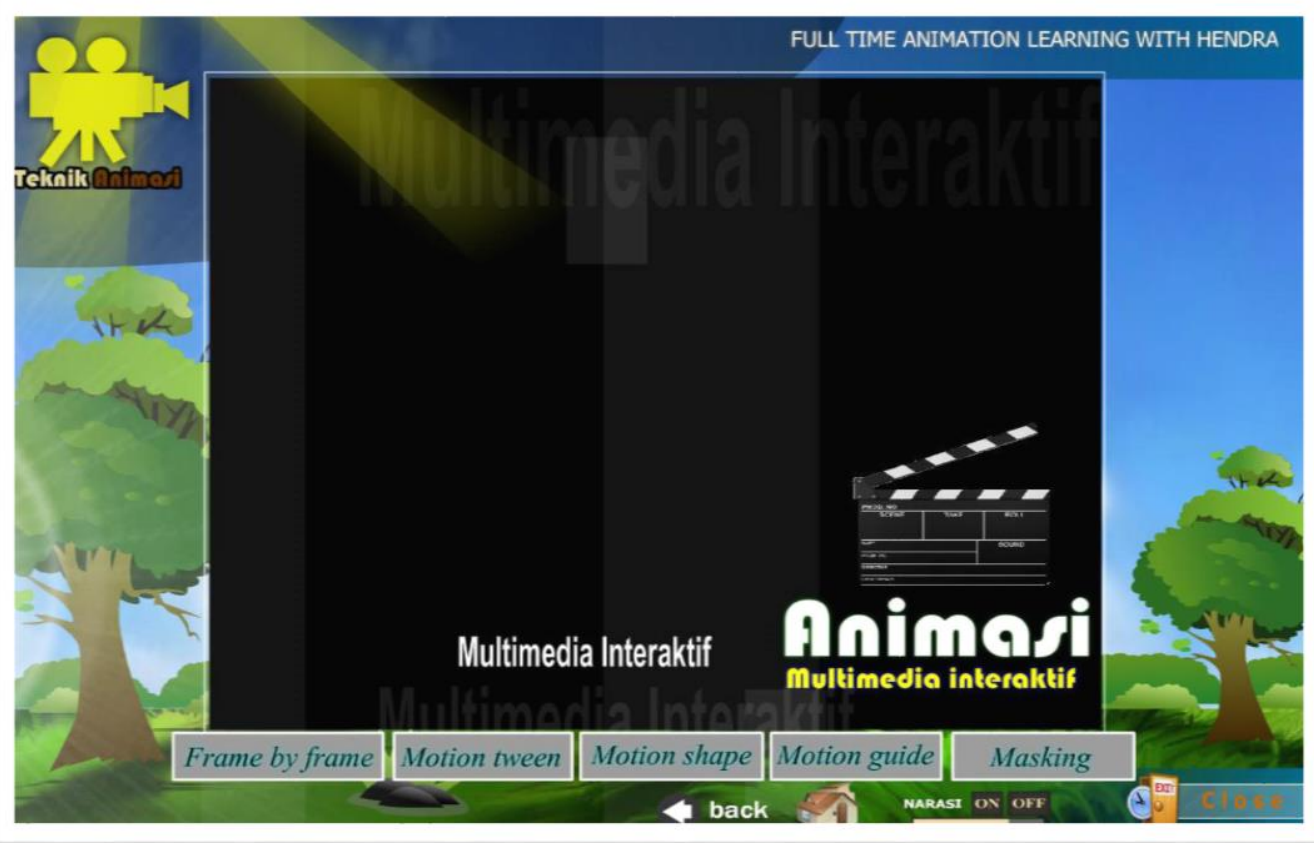

Figure 4. The View of Video Tutorial Page 


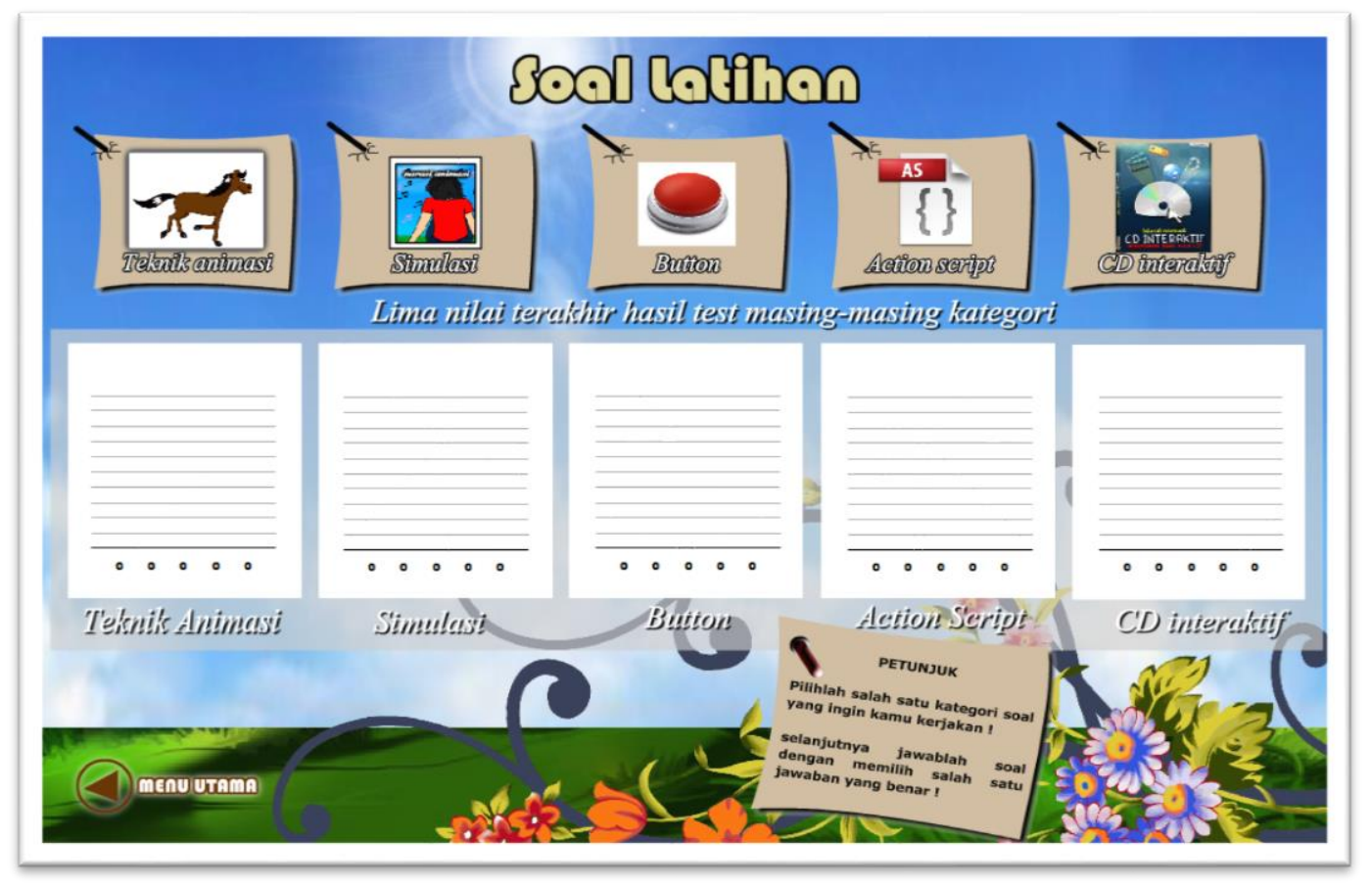

Figure 5. The View of Evaluation Page

After the interactive multimedia animation keys in the process of finishing, the interactive multimedia is examined by content expert and media expert, the person who is indicated as a media expert is the person who is competent in the animation field. And the score for each point in the questionaire is 5 , so the presentage is calculated. First find out the total score for each point and then totaling the result of the highes point which is multiplied by the total item. Next, the precentage is calculated: $45: 50 \times 100 \%=90 \%$ and $90 \%$ means a very good qualification. Next, who is indicated as a content expert is a teacher of animation key subject by measure the suitability of the material presented, and the response of 30 students of class XII multimedia in SMK N 1 Sawan. Practically aspec of using interactive multimedia animation key and the content prsented is examined by the user who will use the interactive multimedia animation key, teacher and students. Here are the results of testing using a media expert with the conversion level of achievement with the scale 5 is used as a reference in the calculation of media experts.

Table 1. Convertion of the acvhievement rate with scale 5 on media expert

\begin{tabular}{ccc}
\hline Achievement Rate (\%) & Qualification & Description \\
\hline $90-100$ & Very Good & No Revision \\
$75-89$ & Good & No Revision \\
$65-74$ & Enough & Revised \\
$55-64$ & Bad & Revised \\
$0-54$ & Very Bad & Revised \\
\hline
\end{tabular}

Table 2. The result of media expert questionaire

\begin{tabular}{llll}
\hline No & Instrument & $\begin{array}{l}\text { Research Result } \\
\text { Average score }\end{array}$ & Category \\
\hline 1 & Coloration & 4 & Appropriate \\
2 & Word and language used & 5 & Very Appropriate
\end{tabular}




\begin{tabular}{llll}
3 & Graphic & 4 & Appropriate \\
4 & Animation & 5 & Very Appropriate \\
5 & Video & 5 & Very Appropriate \\
6 & Sound & 4 & Appropriate \\
7 & Program operation & 4 & Appropriate \\
8 & Program Safety & 4 & Appropriate \\
9 & Error handling & 5 & Very Appropriate \\
10 & Physical Packaging Quality & 5 & Very Appropriate \\
\hline Average & 45 & Very Good \\
\hline
\end{tabular}

Table 3. Result of Teacher's Response Questionaore Analysis

\begin{tabular}{llll}
\hline \multirow{2}{*}{ No } & Instrument & $\begin{array}{l}\text { Research Result } \\
\text { Average score }\end{array}$ & Category \\
\hline 1 & Interactive Multimedia Animation key & 45 & Very Positive \\
2 & In accordance with LKS Animation Key & 43 & Very Positive \\
3 & $\begin{array}{l}\text { In accordance with the lesson plan of interactive } \\
\text { Multimedia Animation Key }\end{array}$ & 44 & Very Positive \\
& $\begin{array}{l}\text { User Guide/ Guide books on how to use the Interactive } \\
4\end{array}$ & 44 & Very Positive \\
\hline Average & 44 & Very Positive \\
\hline
\end{tabular}

Table 4. Result of Student's Response Questionaore Analysis

\begin{tabular}{|c|c|c|c|}
\hline \multirow{2}{*}{ No } & \multirow{2}{*}{ Instrument } & \multicolumn{2}{|l|}{ Research Result } \\
\hline & & Average score & Category \\
\hline 1 & Interactive Multimedia Animation key & Very Positive & Very Positive \\
\hline 2 & In accordance with LKS Animation Key & Very Positive & Very Positive \\
\hline 3 & In accordance with the lesson plan of interactive Multimedia Animation Key & Very Positive & Very Positive \\
\hline 4 & User Guide/ Guide books on how to use the Interactive Multimedia Animation Key & Very Positive & Very Positive \\
\hline \multicolumn{2}{|c|}{ Average } & 45 & Very Positive \\
\hline
\end{tabular}

Table 5. The result study of students

\begin{tabular}{cccccc}
\hline No & Total Studennts & Average & Completeness & Absorption & description \\
\hline 1 & 30 & 81.05 & $96 \%$ & $80 \%$ & Complete \\
\hline
\end{tabular}

\section{Discussion}

All the result of development research of interactive multimedia animation keys will be presented at the discussion they are interactive multimedia that is developed by using the model of Dick \& Carey, the stages which determine the subjects which were the objects of development, content needs analysis, the process of media development, production, expert review and testing, the subject matter that is presented in succession based on the inputs of experts content and media experts, testing of the user/teacher/educators, student response calculation and measure student learning outcomes.

These stages including:

1. Determining Animation Subject as the Object of Development.

The subject developed in the manufacture of interactive multimedia is an animation key subject that is a part of a group of multimedia productive subjects which is belonging to the manufacturing of multimedia products. 


\section{Content needs analysis}

Content need analysis is a stage to analyze everything that is needed in the draft development such analysis of the purpose and characteristics of the subjects, the analysis of learning resources and analysis of learner characteristics. In this phase is to collect data obtained in class XII Multimedia SMK Negeri 1 Sawan related to animation key learning. Animation learning requires students to be more creative, while the less of time allocation to make the students impressed rush in the creating the product, and the time given just enough to keep the material provided during the learning process. To solve this problem students need an interactive multimedia animation key learning in which there are the guidelines in making animation so that students can learn at home, by utilizing the laptop / computer that they have so students are free to be creative with their creativity to create want they want.

\section{Media development Process}

At this stage is to determine Competency Standards (SK), Basic Competency (KD) and the Education Indicators and determine the materials to be used in the creating the interactive multimedia animation keys in class XII Multimedia of SMK Negeri 1 Sawan.

\section{Interactive multimedia Animation Key Production}

There are steps in this stage, they are: design and software, implementation and testing unit and also integration and media testing.

5. Expert Review and Trials

After the interactive multimedia animation key is done it will be held a review and the trial process by experts who have a role as media expert and content expert in this reseacrh. User trial is conducted by the teachers of the class XII Multimedia at SMK Negeri 1 Sawan. And students trial as respondents of this research is done by 30 students. At the stage of review and trials, there are several times of repair process. The results of these steps may be seen from the results of content expert assessment, expert testing of learning media, expert testing of learning design, the result of teacher assesment, and also the result of students as respondents testing. The results of media expert assessment get an average score 45 with a percentage of $90 \%$ are in excellent qualifications, and then analysis of the teachers' response as a user obtain the average score 44 and belong to the category very positive, and the response of the students gained an average score 45 and belong to the category very positive. And then from 30 students, they can get 81,05 average score with a level of completeness $96 \%$ and $80 \%$ absorption. So the average of student learning outcomes in animation key material is complete. With these results, it is proved that interactive multimedia is able to improve the response and the outcomes of the students in the learning process. It is in line with a statement from Arsyad (2011) which states that learning media can improve and guide the students' attention, so it can motivate students in learning proces, improve the direct interaction between the students and the environment, and allow students to learn by their own selves based on their ability and interest. The interesting learning atmosphere, which is different from the usual can make the students enjoy the learning proces, it will give the positive effect to the result of the study.

\section{Conclusion}

Based on the analysis of data and discussion on development research of Interactive multimedia animation keys, it can be concluded that: (1) Development of interactive multimedia animation key in class XII Multimedia SMK Negeri 1 Sawan is designed to provide a source of additional learning for students it can enhance the spirit of students in learning proces whether it is at school or at home, and (2) the response of students to the development of interactive multimedia animation key in class XII Multimedia SMK Negeri 1 Sawan showed that the percentage of students with 45 average score and belong to the very positive category. (3) And then from 30 students, they can obtain 81.05 average score of their learning outcomes with $96 \%$ level of completeness and $80 \%$ absorption, so the average of student learning outcomes in animation key material is complete. Based on the conclusions above, it is suggested that the development of interactive multimedia should be developed for the subject or the other basic competence, especially in the subject of multimedia or other subjects in general 


\section{References}

Arsyad, A. 2011. Media pembelajaran. Jakarta:PT Raja grafindo Persada.

Laurahasiel. $2009 . \quad$ "Multimedia Dalam Pembelajaran". http://laurahasiel.wordpress.com/2009/06/19/Multimedia-Dalam-Pembelajaran/, diakses tanggal 10 Juli 2009

Munadi, Y. 2008. Media Pembelajaran; Sebuah Pendekatan Baru. Jakarta: Gaung Persada Press.

Oemar Hamalik, 1994. Teknik pengukuran dan evaluasi pendidikan. Bandung: Mandar maju

Santyasa, I. W. 2007. Landasan Konseptual Media Pembelajaran. Makalah Disajikan dalam Workshop Media Pembelajaran bagi Guru-Guru SMA Negeri Banjar Angkan. Klungkung 10 Januari 2007.

Soenarto. 2005. Metodologi Penelitian Pengembangan untuk Peningkatan Kualitas Pembelajaran (research Methodology to The Improvent Of Instruction). Makalah Disampaikan pada Pelatihan Nasional Penelitian Peningkatan Kualitas Pembelajaran dan Penelitian Tindakan Kelas (PPKP dan PTK) Bagi Dosen LPTK. Denpasar: Agustus.

Supriatna, Dadang. 2003. Konsep Dasar Desain Pembelajaran. (Tidak diterbitkan). Makalah disampaikan pada Diklat E-Training PPPPTK TK dan PLB. Pusat Pengembangan Dan Pemberdayaan Pendidik Dan Tenaga Kependidikan Taman Kanak Kanak Dan Pendidikan Luar Biasa. 